\title{
Improvements in the enzymatic degradation of textile dyes using ionic-liquid-based surfactants
}

Rui M. F. Bento, Mafalda R. Almeida, Pankaj Bharmoria, Mara G. Freire, Ana P. M. Tavares*

CICECO - Aveiro Institute of Materials, Department of Chemistry, University of Aveiro, 3810-193 Aveiro, Portugal

*Corresponding author

E-mail address: aptavares@ua.pt 


\section{Abstract}

The intensive use of water containing dyes by the textile industry, and consequently the contamination of soils and water, represents serious environmental concerns. Amongst the several processes applied in the treatment of textile effluents, biological-based processes, if designed to be cost-effective and ecofriendly, are promising alternatives to decolorize textile effluents. In this work we investigate and propose the novel use of ionic liquids (ILs) with surfactant characteristics to improve the degradation of the largely used and highly hydrophobic textile dye indigo carmine by laccase. An initial screening on the activity of laccase in aqueous solutions of twelve surfactant-based ILs from three different families, namely tetraalkylammonium- and imidazolium-based cationic surfactants and cholinium-based anionic surfactants, at different concentrations, was carried out. A high activity of laccase was observed with decyltrimethylammonium bromide, $\left[\mathrm{N}_{10111}\right] \mathrm{Br}$, and 1-decyl-3-methylimidazolium chloride, $\left[\mathrm{C}_{10} \mathrm{mim}\right] \mathrm{Cl}$, at $75 \mathrm{mM}$ (above the critical micellar concentration of each IL). These ILs were then investigated in aqueous solutions to simultaneously encapsulate laccase and IC for the in situ enzymatic biodegradation of the dye. The use of ILs remarkably increases the degradation rate of the dye and decolorization efficiency; a degradation efficiency of IC of $82 \%$ is attained in $0.5 \mathrm{~h}$ using aqueous solutions of $\left[\mathrm{N}_{10111}\right] \mathrm{Br}$, whereas without IL only $6 \%$ of IC is degraded. Furthermore, at the end of $24 \mathrm{~h}, 93 \%$ of the dye decolorization was achieved in the presence of $75 \mathrm{mM}$ of $\left[\mathrm{N}_{10111}\right] \mathrm{Br}$. The overall gathered results show that it is possible to significantly improve the degradation of hydrophobic dyes by enzymes using appropriate surfactant-based ILs, while foreseeing the use of the treated water by the same textile industries in new dyeing steps and thus contributing to a substantial decrease of the economic input and environmental footprint of these industries. 
Keywords: Laccase; enzymatic activity; surfactant-based ionic liquids; indigo carmine; textile aqueous effluents. 


\section{Introduction}

Serious environmental concerns have arisen due to industrial developments, leading to significant risks to human health and to the ecosystem (1). In particular, the textile industry plays a pivotal role contributing to these concerns. Textiles production requires several stages of mechanical processing, involving the discharge of a wide variety of pollutants such as textile dyes (2). Furthermore, the textile industry is highly water intensive, requiring about $200 \mathrm{~L}$ of water to produce $1 \mathrm{~kg}$ of textiles $(3,4)$. The textile effluents are enriched in dyes used in the dyeing process, many of them toxic and mutagenic (5). Synthetic dyes, such as indigo carmine (IC) - a typical recalcitrant dye, are highly persistent and their removal from wastewater is difficult since they are designed to be chemically and photolytically stable (6). Accordingly, the removal and degradation of dyes is a challenging issue from the environmental perspective because conventional methods for the treatment of aqueous systems, such as ozonation, coagulation-flocculation, oxidation, precipitation, adsorption and ion exchange are not totally effective in dyes removal $(1,7,8)$. Therefore, the development of new strategies for the removal or degradation of dyes from textile effluents, ideally allowing the water recycling by the same textile industry, is in high demand.

Biological-based treatment technologies, if designed to be cost-effective and ecofriendly technologies, are promising alternatives to decolorize textile effluents (9). Bioremediation using enzymes have gained significant notoriety due to its versatility and efficiency in the degradation of persistent organic pollutants from wastewater $(10,11)$. Oxidative enzymes such as laccases, peroxidases and tyrosinases have high potential in the oxidation of persistent environmental pollutants (12). These enzymes have the capacity to convert the target pollutants into less toxic or insoluble compounds, which can be then removed from effluents (13). Laccase (benzenodiol oxygen oxidoreductase, 
EC 1.10.3.2) is an efficient multicopper oxidase exhibiting a broad substrate specificity, e.g. phenols and aromatic amines, being thus used in industrial, biotechnological and environmental applications $(14,15)$. More specifically, its ability to degrade a variety of dyes $(16,17)$, such as IC largely used by the textile industry, leads to its use in bioremediation processes with the aim of reducing the environmental impact caused by textile industrial effluents (18). However, the efficient application of enzymes in industrial processes is not always successful due to the enzymes labile nature and loss of stability and enzymatic activity (19).

The use of micellar systems and emulsions can improve catalytic reactions due to the enzyme superactivity phenomenon, being micellar enzymology a hot topic of research (20). In addition to conventional and largely used surfactants, ionic liquids (ILs) with surfactant properties can be designed and applied in the micellar enzymology field. ILs have gained particular importance in the field of biocatalysis and are currently recognized as promising solvent media $(21,22)$. ILs generally exhibit large organic cations and a variety of anions that can be organic or inorganic, which leads to a decrease of these salts melting temperatures when compared to conventional salts $(23,24)$. Being organic salts, most aprotic ILs display negligible vapor pressures, low flammability, and high thermal and chemical stability (25). Furthermore, due to their tunable character achieved by altering the anion or cation chemical structure, it is possible to tailor the properties of ILs and to synthesize a specific IL to a target reaction or application. Accordingly, long alkyl side chain ILs, if properly designed, may be amphiphilic compounds able to selfaggregate and form micelles $(26,27)$. A wide range of ILs has been characterized in terms of their critical micellar concentration (CMC), being investigated in several applications as alternative surfactants or as co-surfactants $(28,29)$. 
Besides the large number of studies demonstrating the ability of ILs to form micelles and determination of their CMC values, fewer works addressed the use of ILs with surfactant characteristics to improve enzymatic bioreactions $(28,29)$. In this work, we investigate and propose the use of ILs with surfactant behavior to improve the degradation of the IC dye by laccase, which may allow the reuse of the discharged water by the textile industry.

\section{Experimental}

\subsection{Chemicals}

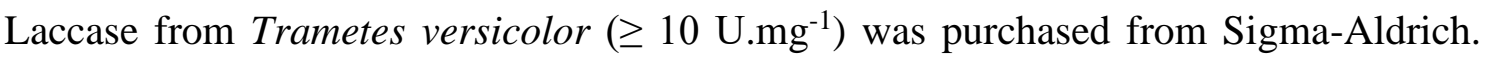
Three families of ILs were investigated, namely 1-alkyl-3-methylimidazolium chloride and 1-alkyl-trimethylammonium bromide (acting as cationic surfactants), and cholinium carboxylates (acting as anionic surfactants). The cationic surfactant-based ILs 1-methyl3-octylimidazolium chloride (>98\% purity), 1-decyl-3-methylimidazolium chloride (>98\% purity), 1-dodecyl-3-methylimidazolium chloride (>98\% purity), 1-methyl-3tetradecylmethylimidazolium chloride ( $>98 \%$ purity), were purchased from Iolitec. Octyltrimethylammonium bromide (98\% purity) and decyltrimethylammonium bromide (99\% purity) were acquired from TCI Europe N.V. Dodecyltrimethylammonium bromide (99\% purity) and tetradecyltrimethylammonium bromide (98\% purity) were supplied by Alfa Aesar. The cholinium-based carboxylates, namely cholinium octanoate, cholinium decanoate, cholinium dodecanoate and cholinium tetradecanoate were synthesized by us according to the protocol described in the literature (30). The abbreviation, molecular weight and critical micellar concentration (CMC) of all ILs are given in Table 1, and the ILs chemical structures are shown in Figure 1. The enzyme substrate 2,2'-azino-bis(3ethylbenzothiazoline-6-sulfonic acid) diammonium salt (ABTS) was obtained from Sigma-Aldrich. Indigo carmine (IC) (C.I. 73015) was supplied by ACROS Organics ${ }^{\mathrm{TM}}$. 
The chemical structure and properties of IC are provided in Table 2. All aqueous solutions were prepared using Milli-Q ultrapure water.

Table 1. Name, abbreviation, molecular weight and critical micellar concentration (CMC) of the surfactant-based ionic liquids (ILs) studied.

\begin{tabular}{|c|c|c|c|}
\hline IL & Abbreviation & $\begin{array}{c}\text { Molecular } \\
\text { weight }\left(\text { g.mol }^{-1}\right)\end{array}$ & $\begin{array}{c}\mathbf{C M C}(\mathbf{m M}) \\
(31-33)\end{array}$ \\
\hline octyltrimethylammonium bromide & {$\left[\mathrm{N}_{8111}\right] \mathrm{Br}$} & 252.23 & 130.0 \\
\hline decyltrimethylammonium bromide & {$\left[\mathrm{N}_{10111}\right] \mathrm{Br}$} & 280.29 & 64.6 \\
\hline dodecyltrimethylammonium bromide & {$\left[\mathrm{N}_{12111}\right] \mathrm{Br}$} & 308.34 & 15.6 \\
\hline tetradecyltrimethylammonium bromide & {$\left[\mathrm{N}_{14111}\right] \mathrm{Br}$} & 336.39 & 3.6 \\
\hline 1-methyl-3-octylimidazolium chloride & {$\left[\mathrm{C}_{8} \operatorname{mim}\right] \mathrm{Cl}$} & 230.78 & 233.0 \\
\hline 1-decyl-3-methylimidazolium chloride & {$\left[\mathrm{C}_{10} \mathrm{mim}\right] \mathrm{Cl}$} & 258.83 & 58.7 \\
\hline 1-dodecyl-3-methylimidazolium chloride & {$\left[\mathrm{C}_{12} \mathrm{mim}\right] \mathrm{Cl}$} & 286.88 & 15.2 \\
\hline $\begin{array}{l}\text { 1-methyl-3-tetradecylmethylimidazolium } \\
\text { chloride }\end{array}$ & {$\left[\mathrm{C}_{14} \mathrm{mim}\right] \mathrm{Cl}$} & 314.94 & 3.9 \\
\hline cholinium octanoate & {$[\mathrm{Ch}]\left[\mathrm{C}_{8} \mathrm{O}_{2}\right]$} & 247.37 & 303.3 \\
\hline cholinium decanoate & {$[\mathrm{Ch}]\left[\mathrm{C}_{10} \mathrm{O}_{2}\right]$} & 275.43 & 104.3 \\
\hline cholinium dodecanoate & {$[\mathrm{Ch}]\left[\mathrm{C}_{12} \mathrm{O}_{2}\right]$} & 303.48 & 25.8 \\
\hline cholinium tetradecanoate & {$[\mathrm{Ch}]\left[\mathrm{C}_{14} \mathrm{O}_{2}\right]$} & 331.53 & 7.0 \\
\hline
\end{tabular}




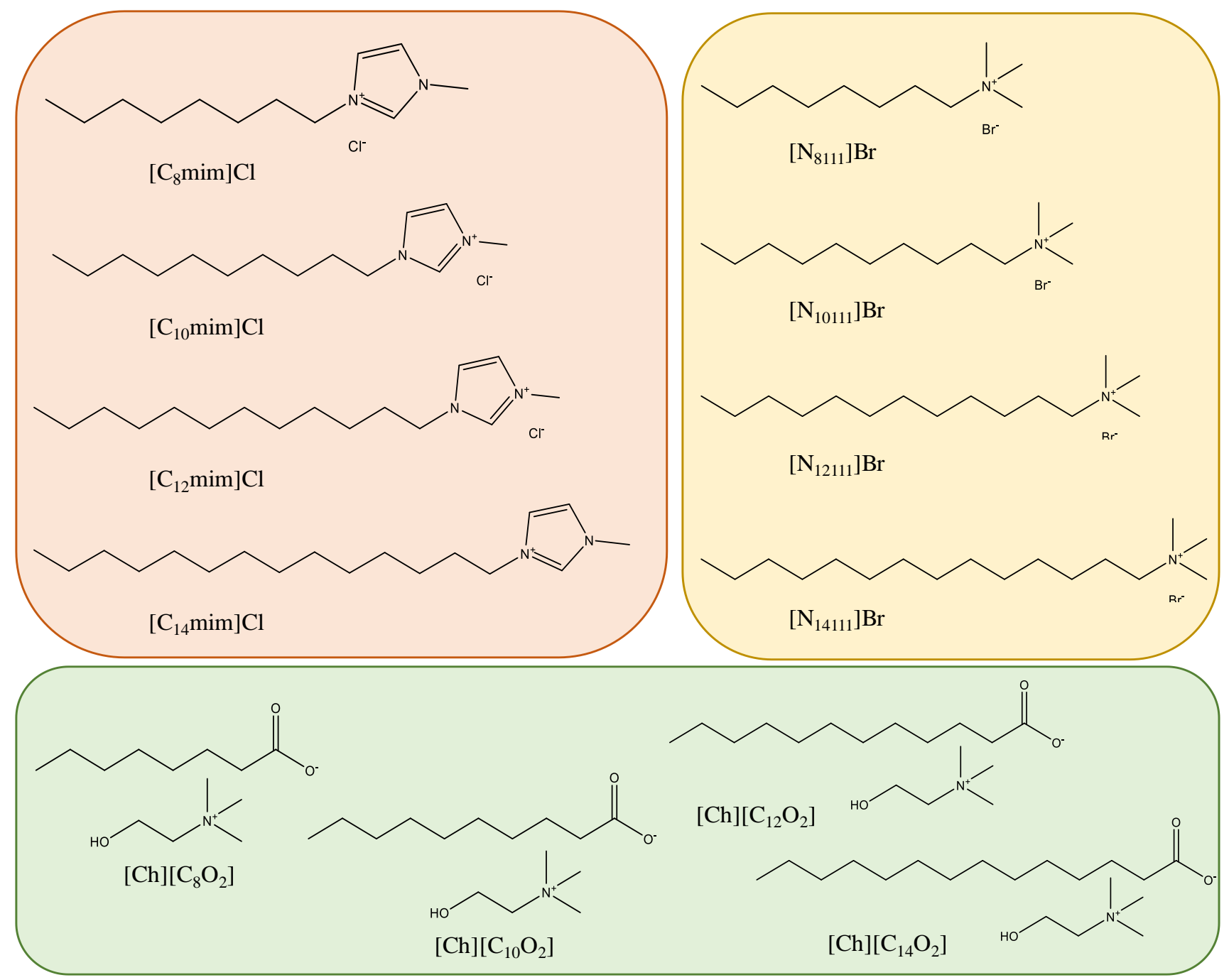

Fig.1. Chemical structure of the surfactant-based ionic liquids investigated. 
Table 2. Structure and properties of the indigo carmine (IC) dye used in the micellar enzymatic degradation tests (34).

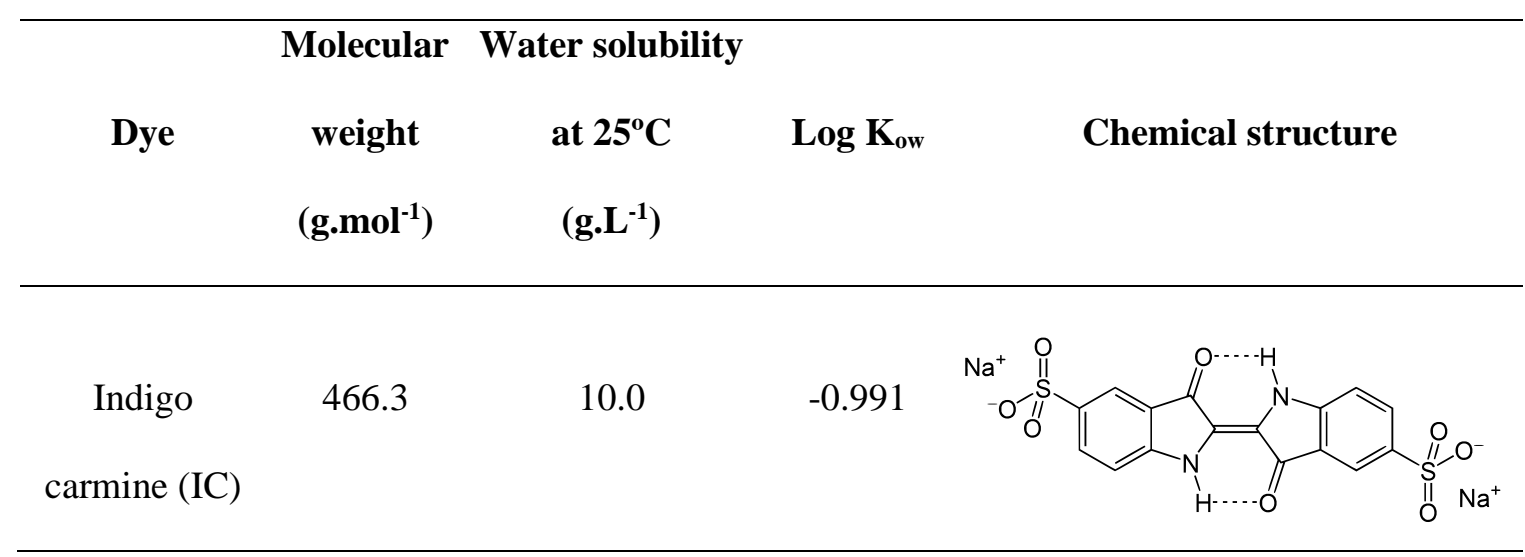

3

4 2.2. Laccase activity in aqueous solutions of surfactant-based ILs

5 An initial screening on potential ILs to improve the laccase activity was carried out. To

6 this end, aqueous solutions containing laccase and ILs were prepared with a final enzyme

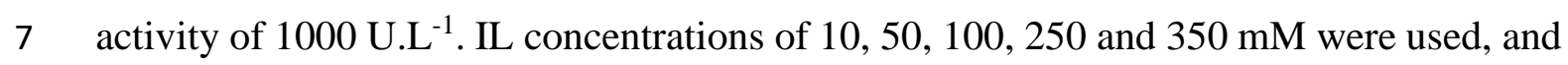

8 assays were performed at room temperature (ca. $25^{\circ} \mathrm{C}$ ) and $\mathrm{pH} 4.5$ (adjusted with $\mathrm{HCl} 0.5$

9 M). A control solution was used, with no addition of IL, at the same experimental

10 conditions. The laccase activity in presence of ILs was determined

11 spectrophotometrically by monitoring the oxidation of ABTS at $420 \mathrm{~nm}(\varepsilon=36.000$

$12 \mathrm{M}^{-1} \mathrm{~cm}^{-1}$ ), using a SHIMADZU UV-1800, UV-Vis Spectrophotometer. The enzymatic

13 reaction was carried out by adding $50 \mu \mathrm{L}$ of sample in $250 \mu \mathrm{L}$ of ABTS $1.6 \mathrm{M}$ and 700

$14 \mu \mathrm{L}$ of Milli-Q water (adjusted at $\mathrm{pH} 4.5$ with $\mathrm{HCl} 0.5 \mathrm{M}$ ). One unit (U) of laccase activity

15 is defined as the amount of enzyme that oxidized $1 \mu \mathrm{mol}$ of ABTS (molar extinction

16 coefficient $\left[\varepsilon_{420}\right], 36,000 \mathrm{M}^{-1} \mathrm{~cm}^{-1}$ ) per minute. The laccase activity is presented in $\mathrm{U}^{-} \mathrm{L}^{-}$

171 . All assays were repeated at least three times. 
2 Surfactant-based ILs in which the enzyme showed higher activities were selected to study

3 the enzymatic degradation of IC. The decolorization of IC was evaluated by the

4 monitorization of the absorbance at $608 \mathrm{~nm}$ using a SHIMADZU UV-1800, UV-VIS

5 Spectrophotometer. The enzymatic reaction mixture contained: $2.50 \mathrm{~mL}$ of Milli-Q water 6 at $\mathrm{pH} 4.5,1.25 \mathrm{~mL}$ of IC (25 mg.L $\left.\mathrm{L}^{-1}\right), 1.25 \mathrm{~mL}$ of laccase (1000 U.L $\left.\mathrm{L}^{-1}\right)$ and IL (20 and 75

$7 \mathrm{mM}$, below and above the CMC of the ILs used in this step, respectively). Control 8 aqueous solutions composed of each IL and of IC were used. At the same conditions, no 9 dye degradation was observed with these solutions, showing that laccase is responsible 10 for the dye degradation.

11 The decolorization of IC extent was determined according to equation 1:

$$
\text { IC decolorization }(\%)=\left(\frac{A_{0}}{A_{t}}\right) \times 100
$$

where $A_{0}$ and $A_{t}$ are the initial absorbance and the absorbance observed at a certain time (t), respectively. All assays were performed in triplicate.

\subsection{Circular dichroism spectroscopy}

17 The laccase secondary structure in presence of $\left[\mathrm{N}_{10111}\right] \mathrm{Br}$ and $\left[\mathrm{C}_{10} \mathrm{mim}\right] \mathrm{Cl}$ was evaluated by circular dichroism (CD) spectroscopy using a Jasco J-1500 CD spectrometer. Aqueous solutions containing laccase and $\left[\mathrm{N}_{10111}\right] \mathrm{Br}$ or $\left[\mathrm{C}_{10 \mathrm{mim}}\right] \mathrm{Cl}$ were prepared with a final enzyme concentration of $0.6 \mathrm{mg} \cdot \mathrm{mL}^{-1}$. We could not use high concentrations of ILs on ground of the fact that the studied ILs shows very high absorbance in the far UV region beyond $1 \mathrm{mM}$. "Blank" solutions at the same IL concentrations (with no laccase added) were used to remove the ILs interference on the CD spectrum. A control using aqueous laccase solution was used. CD spectra were recorded from 190 to $260 \mathrm{~nm}$ using quartz 
1 CD cuvettes $(0.1 \mathrm{~cm})$ at room temperature. Each $\mathrm{CD}$ spectrum is the result of five

2 accumulations recorded in millidegrees. The following acquisition parameters were used:

3 data pitch, $1.0 \mathrm{~nm}$; sensitivity $100 \mathrm{mdeg}$; response time $4 \mathrm{~s}$; bandwidth, $0.50 \mathrm{~nm}$; and scan

4 speed, $100 \mathrm{~nm} \cdot \mathrm{min}^{-1}$. A smooth was performed in each CD spectrum using the following

5 parameters: method, Savitzky-Golay; convolution width, 7.

6

$7 \quad$ 2.5. Analysis by optical microscopy

8 To evaluate the microscopic appearance of the micellar $\left[\mathrm{N}_{10111}\right] \mathrm{Br}$ solutions, different

9 samples were prepared: IL (75 mM) and IC (25 mg.L $\left.\mathrm{L}^{-1}\right)$; IL (75 mM) and laccase (1000

U.L $\left.{ }^{-1}\right)$ and IL (75 mM), laccase (1000 U.L $\left.\mathrm{L}^{-1}\right)$ and IC (25 mg.L $\left.\mathrm{L}^{-1}\right)$. The solutions were centrifuged (microfuge Star 17, VWR) at increasing speeds from 300 to $13300 \mathrm{rpm}$ attempting the aggregates precipitation. Microscopic images of the precipitated fraction were obtained using a polarized light microscope, Olympus BX51 with $100 \times$ and $200 \times$ magnifications.

\section{Results and Discussion}

\subsection{Laccase activity in aqueous solutions of surfactant-based ILs}

The development of the micellar enzymology concept, applying surfactant-based ILs, has been a hot topic of research due to the enzymes superactivity phenomenon afforded by amphiphilic ILs (20). However, the role of the IL chemical structure and properties on the laccase activity and further applications is still scarce. Thus, it is of high importance 
1 to identify appropriate IL-based surfactants able to improve the catalytic activity of

2 laccases and related bioreactions performance.

3 Since enzyme-catalyzed reactions are strongly influenced by the reaction solvent

4 medium, the chemical structure and concentration of a series of IL-based surfactants were

5 first evaluated toward the laccase activity. Aqueous solutions with laccase at a final

6 concentration of enzyme of $\sim 1000$ U.L ${ }^{-1}$ and ILs with concentrations of 10, 50, 100, 250

7 and $350 \mathrm{mM}$ were investigated. These concentrations were selected to be below and

8 above the CMC of each IL (cf. Table 1). Twelve surfactant-based ILs from three different

9 families, namely tetraalkylammonium- and imidazolium-based cationic surfactants and

10 cholinium-based anionic surfactants were investigated. A control solution (with no IL at

11 the same experimental conditions - $\mathrm{pH} 4.5$ adjusted with $\mathrm{HCl} 0.5 \mathrm{M}$ ) was prepared and

12 always used for comparison purposes. The relative laccase activity in the different IL aqueous solutions is depicted in Figure 2, whose detailed results are provided in Table S1 in the Supporting Information. The relative laccase activity corresponds to the percentage activity of laccase in the control in respect to each IL aqueous solution.

The results obtained show that reactions catalyzed by laccase are considerably influenced by the IL chemical structure, i.e. if it is an anionic or cationic surfactant, and by the IL concentration. In general, the laccase activity in presence of the cationic tetraalkylammonium- and imidazolium-based surfactants is higher at lower IL concentrations and with ILs with shorter alkyl side chains, reaching values similar to the control ( $>85 \%$ of relative activity) with the following ILs at the following concentrations: $\left[\mathrm{N}_{8111}\right] \mathrm{Br}$ at 10 and $50 \mathrm{mM}$; $\left[\mathrm{N}_{10111}\right] \mathrm{Br}$ at 10,50 and $100 \mathrm{mM} ;\left[\mathrm{C}_{8} \mathrm{mim}\right] \mathrm{Cl}$ at 10,50 and $100 \mathrm{mM} ;\left[\mathrm{C}_{10 \mathrm{mim}}\right] \mathrm{Cl}$ at 10,50 and $100 \mathrm{mM} ;\left[\mathrm{C}_{12} \mathrm{mim}\right] \mathrm{Cl}$ at $10 \mathrm{mM}$; and $\left[\mathrm{C}_{14} \mathrm{mim}\right] \mathrm{Cl}$ at $10 \mathrm{mM}$. The dependence of the laccase activity with the alkyl chain length can be 
1 moieties of the enzyme which can affect the enzyme conformational structure and 2 consequently its reactivity $(35,36)$. Among these, $\left[\mathrm{C}_{10} \mathrm{mim}\right] \mathrm{Cl}$ and $\left[\mathrm{N}_{10111}\right] \mathrm{Br}$ at $75 \mathrm{mM}$

3 are above the respective CMC values (Table 1), meaning that micelles are present. On the

4 other hand, the laccase activity in presence of cholinium-based ILs (anionic surfactants)

5 is not favored; in fact, a maximum relative activity of $50 \%$ has been observed with these

6 ILs when compared to the control. Furthermore, the laccase activity decreases with the

7 increase in the IL concentration. These results indicate that the studied anionic surfactants

8 act as inhibitors of laccase. IL ions can interact with the enzyme by electrostatic

9 interactions, occurring between the surfactant head groups and charged amino acid 10 residues, and by hydrophobic forces occurring between the IL alkyl chains and the 11 enzyme hydrophobic cores (37). Moreover, other physicochemical properties of ILs such as polarity, water miscibility, viscosity, and ions charge density may also influence enzymatic activity, and have been studied (38).

In the literature, it is reported that for anionic surfactants, the initial binding between the enzyme and the surfactant occurs on the cationic sites of the enzyme (amino acids side chains) causing the unfolding (denaturation) of the enzyme and the formation of a strong protein-surfactant complex (37). These reported evidences suggest that a similar phenomenon may happen in the current work when addressing anionic IL surfactants. A recent review from Liu et al. (39) describes the ILs features that influence the laccase activity. For instance, the authors stated that there is no correlation between the IL polarity and the laccase activity (39). On the other hand, Yang et al. (40) described that the effect of the ILs' ions on the enzyme stability be explained by the Hofmeister series. Overall, the authors concluded that chaotropic cations and kosmotropic anions stabilize the enzyme, whereas kosmotropic cations and chaotropic anions tend to destabilize it (39). 
1 For our results, it is clear that the catalytic activity of laccase is affected by the IL type

2 and concentration. Taking into account the overall results and the foreseen application of 3 using micellar systems combined with laccase to degrade highly hydrophobic textile dyes,

4 the ILs $\left[\mathrm{N}_{10111}\right] \mathrm{Br}(\mathrm{CMC}=64.6 \mathrm{mM})$ and $\left[\mathrm{C}_{10 \mathrm{mim}}\right] \mathrm{Cl}(\mathrm{CMC}=58.7 \mathrm{mM})$ with a high 5 activity of laccase $(>85 \%)$ at an IL concentration of $75 \mathrm{mM}$ were selected and investigated 6 in the following set of studies regarding the IC decolorization. 


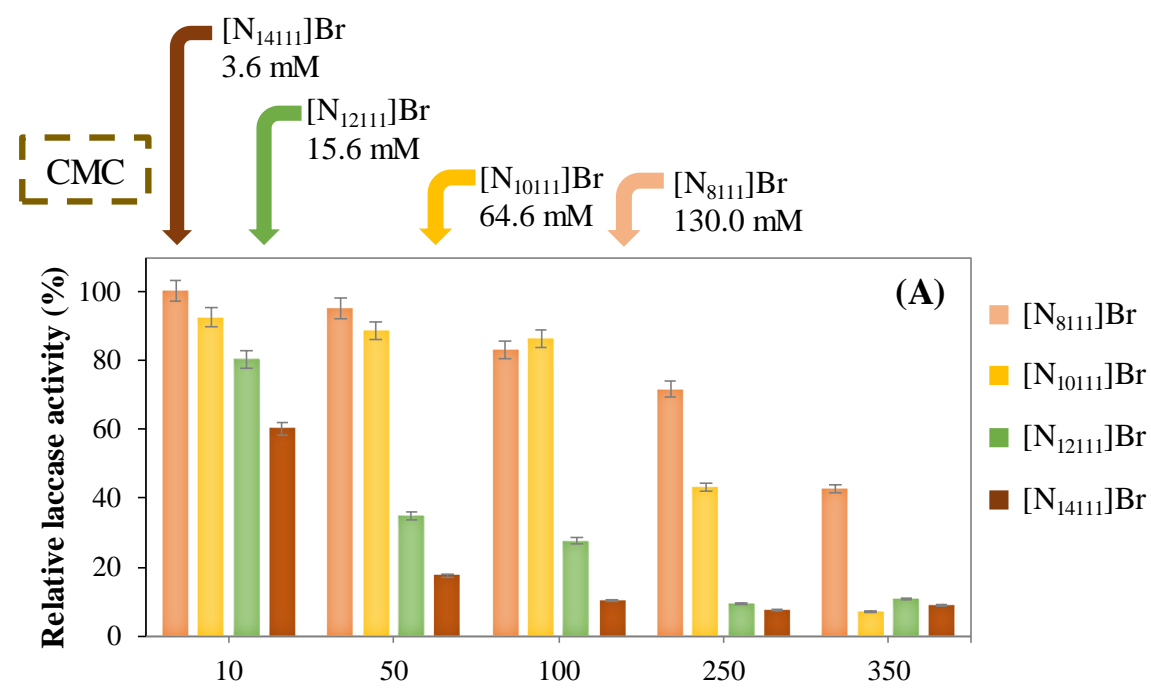

[IL] (mM)

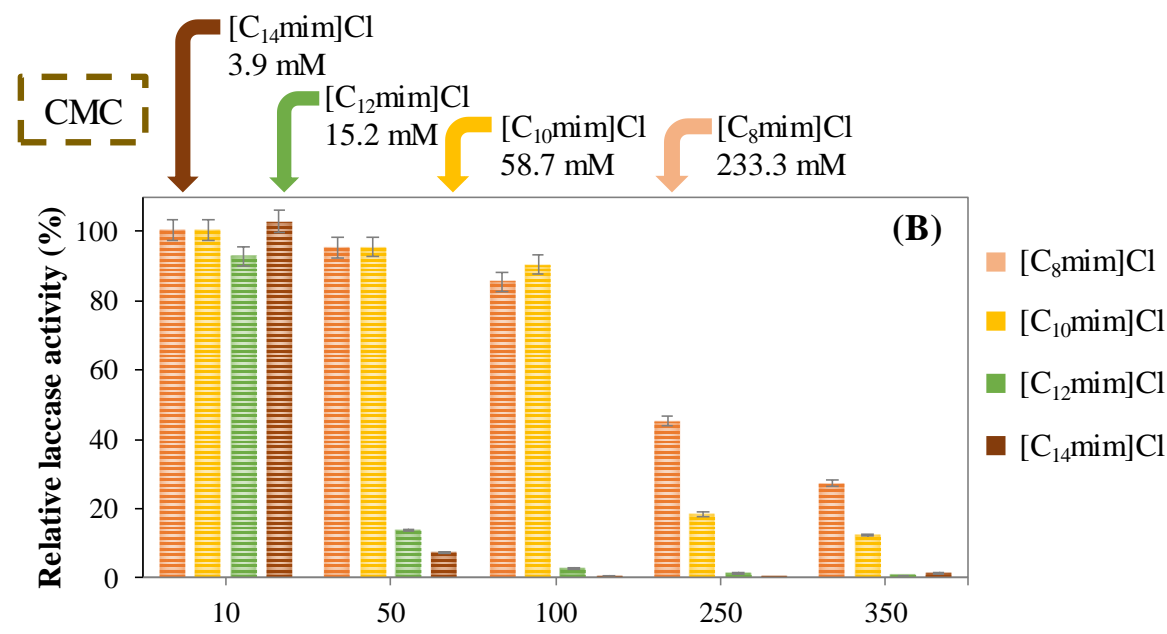

[IL] (mM)

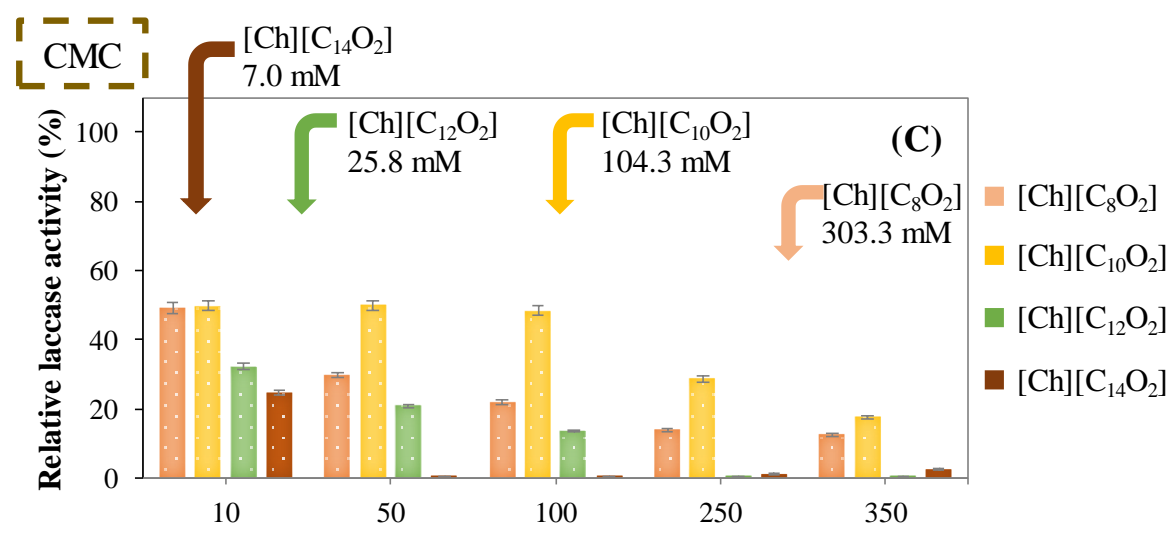

[IL] (mM)

2 Fig. 2. Relative laccase activity (\%) in aqueous solutions composed of (A) ammonium-based 3 ionic liquids (ILs); (B) imidazolium-based ILs; and (C) cholinium-based ILs. Arrows indicate the 4 critical micellar concentration (CMC) of each surfactant-based IL. 
2 The mechanism of IC degradation by laccase was studied by Campos et al. (41). Laccase

3 induces the IC oxidation, resulting in the formation of the indole-2,3-dione intermediate,

4 which is further decomposed into 2-aminobenzoic acid (41). This reaction occurs due to

5 the trinuclear copper centers of laccase that oxidize the dye, transferring the electrons

6 from the substrate to the copper center, while $\mathrm{O}_{2}$ is reduced to water (42). The

7 ecotoxicological features of IC reaction products were evaluated by MicroTox, in which

8 it was demonstrated that they are less toxic than the IC precursor (43). The toxicity of IC

9 degradation products by an enzyme preparation (not defined) was addressed against fish

10 (Talapia) and two bacteria (Escherichia coli and Bacillus subtilus), with no toxicity

11 obtained (44). Furthermore, toxicological studies of IC using an integrated treatment by

12 a trimeric thermostable laccase and a microbial consortium showed that the degradation products were non-toxic, while the initial IC was toxic (45). These results support our strategy on resorting to biocatalysis to perform the degradation of dyes aiming water treatment.

Taking into account that micellar systems are required due to the high hydrophobicity $\left(\log \left(\mathrm{K}_{\mathrm{ow}}\right)\right.$ : -0.991) and low water solubility of IC (cf. Table 2), the effects afforded by $\left[\mathrm{N}_{10111}\right] \mathrm{Br}$ and $\left[\mathrm{C}_{10} \mathrm{mim}\right] \mathrm{Cl}$ at 20 and $75 \mathrm{mM}$ (below and above their $\mathrm{CMC}$ values) on the color removal of IC by laccase were evaluated. Aqueous solutions of ILs above their CMC will allow the formation of micelles able to encapsulate laccase and IC for the in situ enzymatic biodegradation.

22 Controls composed of each IL and IC (individually) were prepared and no degradation of IC was observed, showing the main role and requirement of laccase in the target oxidative reaction. Although there are several studies on the decolorization of dyes by laccase (4650 ), to the best of our knowledge, there are no literature reports on dyes degradation by 
1 enzymes promoted by IL-based surfactants. Figure 3 (A) and Table S2 in the Supporting

2 Information provide the results obtained for the decolorization of IC by laccase in the

3 presence and absence of $\left[\mathrm{N}_{10111}\right] \mathrm{Br}$ or $\left[\mathrm{C}_{10} \mathrm{mim}\right] \mathrm{Cl}$ aqueous solutions. The decolorization

4 of IC by laccase shows a faster and higher catalytic performance in the presence of both

5 surfactant-based ILs at $75 \mathrm{mM}$ when compared to tests performed with $20 \mathrm{mM}$ of IL

6 (below their $\mathrm{CMC}$ ) and the control (laccase with no IL at the same conditions, Figure

7 3(A)), showing the beneficial role of ILs in improving biocatalytic reactions. For instance

8 at $0.5 \mathrm{~h}$ of reaction, the values increase from $6 \%$ of IC decolorization by laccase with no

9 IL added to $30 \%$ and $82 \%$ when using the ILs $\left[\mathrm{C}_{10} \mathrm{mim}\right] \mathrm{Cl}$ and $\left[\mathrm{N}_{10111}\right] \mathrm{Br}$ at $75 \mathrm{mM}$, 10 respectively. Comparing both surfactant-based ILs, $\left[\mathrm{N}_{10111}\right] \mathrm{Br}$ performs better and leads

11 to a higher decolorization efficiency at all times evaluated. Remarkable, after $24 \mathrm{~h}$, an almost complete dye decolorization (>90\%) was achieved, representing an improvement of three times when compared to aqueous solution of ILs at $20 \mathrm{mM}$ to the control with no IL added.

Figure 3 (B) shows the macroscopic appearance regarding the IC decolorization by laccase with $75 \mathrm{mM}$ of $\left[\mathrm{N}_{10111}\right] \mathrm{Br}$. Overall, the obtained results reveal a higher dye decolorization performance by laccase in presence of surfactant-based ILs aqueous solutions. These results do not have the same tendency to the results discussed before, where the laccase activity and the oxidation of ABTS decreases with the increase in the IL concentration. According to Liu et al. (39), laccase has broad substrate specificities, and the design of general rules for selecting efficient ILs-laccase systems is not a straightforward task. For instance, using the same laccase, the activity towards catechol was partially inhibited by 1-butyl-3-methylimidazolium bromide (at $20 \% \mathrm{v} / \mathrm{v}$ ), and completely eliminated when dealing with $\operatorname{ABTS}(51,52)$. Therefore, the enzyme- 
1 substrate affinity should be taken into consideration to define the role of IL in laccase-

2 catalysed reactions.

3 The results of IC decolorization by laccase suggest that by using the respective ILs at

4 concentrations above their CMC, the highly hydrophobic substrate (dye) is inside the

5 micelles as well as the enzyme, turning the dye more accessible to the enzyme in this

6 microenvironment and improving the enzyme catalytic performance. According to the

7 literature, IC cannot be oxidized at high levels by laccase alone. Accordingly, specific

8 laccase mediators, such as 1-hydroxybenzotriazole, 3,5-Dimethoxy-4-

9 hydroxybenzaldehyde, ABTS, violuric acid or N-hydroxyphthalimide $(53,54)$, are

10 usually added to improve the laccase oxidation of IC. In a different approach, IC was

11 degraded by laccase without mediator, but in this case a mutated laccase, with a different

12 active site, was used, allowing to remove a maximum of $\sim 60 \%$ of IC (55). In this work,

13 a fast and efficient degradation of IC without the presence of mediators or enzymes

14 mutation was successfully obtained applying surfactant-based ILs. 

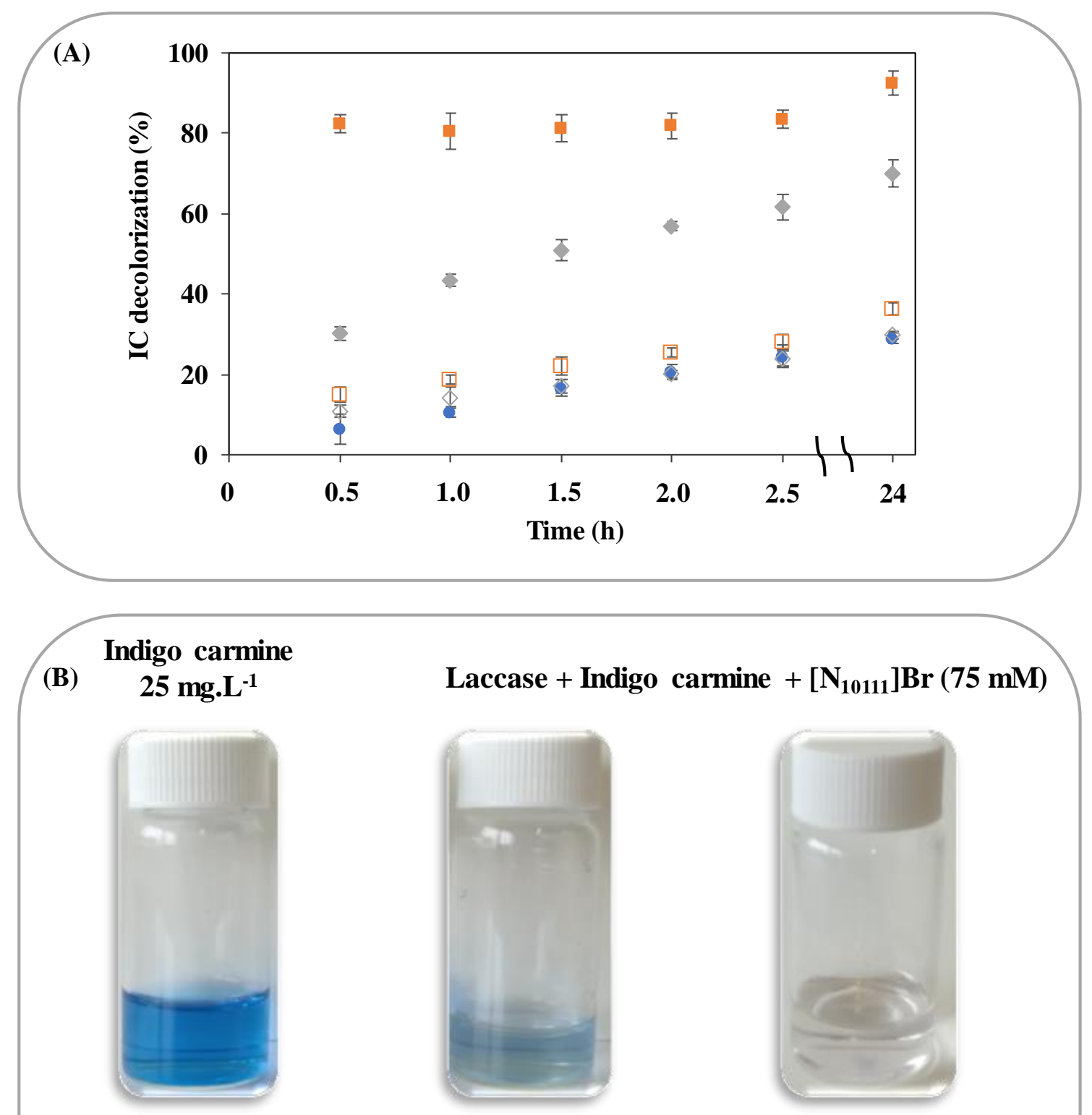

$0 \%$

$83 \%$

$\mathbf{0 ~ h}$

$2.5 \mathrm{~h}$

$93 \%$

$24 \mathrm{~h}$

2 Fig. 3. (A) Indigo Carmine (IC) decolorization by laccase alone

$\bullet$ ), IC decolorization by laccase

3 in $\left[\mathrm{C}_{10} \mathrm{mim}\right] \mathrm{Cl}(75 \mathrm{mM})$ aqueous solutions

$\diamond)$, IC decolorization by laccase in $\left[\mathrm{C}_{10} \mathrm{mim}\right] \mathrm{Cl}(20$

$4 \mathrm{mM})$ aqueous solutions $(\diamond)$, IC decolorization by laccase in $\left[\mathrm{N}_{10111}\right] \mathrm{Br}(75 \mathrm{mM})$ aqueous

5 solutions ( $\square)$, and IC decolorization by laccase in $\left[\mathrm{N}_{10111}\right] \mathrm{Br}(20 \mathrm{mM})$ aqueous solutions $(\diamond)$ at

$625^{\circ} \mathrm{C}$; (B) Images showing the indigo carmine decolorization by laccase in the presence of

$7 \quad\left[\mathrm{~N}_{10111}\right] \mathrm{Br}(75 \mathrm{mM})$ aqueous solutions at $25^{\circ} \mathrm{C}$.

8

9 To better understand the effect of ILs on the structure-activity relation of laccase we evaluated the changes in secondary structure of laccase from CD spectra. The secondary 
1 structure of native laccase shows a characteristic positive peak at around $195 \mathrm{~nm}$ (Figure

2 4, Figure S1 in the Supporting Information) Quantitative analysis of the secondary

3 structure was done using $\mathrm{K}_{2} \mathrm{D}_{3}$ online secondary structural analysis software in the

4 wavelength range of $240-190 \mathrm{~nm}(56,57)$ and found to be $\alpha$-helical $=4 \%$ and $\beta$-sheet $=$ $31 \%$. The calculated secondary structure is in close proximity to that reported for crystal structure of laccase from Trametes versicolor (PDB. IGCY; $\alpha$-helical $=11 \%$ and $\alpha$ helical $=37 \%$ ), hence demonstrating the accuracy of spectral measurement. Moreover, ionic surfactants have been reported to alters the structure of proteins mainly in the low concentration regime, therefore signifying the structural studies at low concentration done in this work. At the studied concentration both ILs, altered the structure of laccase although not significantly (Figure. 4, Figure S1 in the Supporting Information). [ $\left.\mathrm{N}_{10111}\right] \mathrm{Br}$ was found to induce more changes in structure laccase as compared to $\left[\mathrm{C}_{10} \mathrm{mim}\right] \mathrm{Cl}$ indicating the fact that ammonium head group is more interactive with the negatively charged amino acids of laccase as compared to imidazolium possibly due to static charge. Comparing the CD spectra and the IC degradation results using aqueous solutions of ILs at a concentration below the $\mathrm{CMC}$ and laccase, it seems that higher activity of the altered structure of enzyme below CMC can be accounted to the better exposure of active sites to the substrate. Bharmoria et al. (58) have reported that the similar behavior of enzyme cellulase upon interaction with IL 3-methyl-1-octylimidazolium dodecylsulfate, at low concentration. It justifies the fact that the native conformation of the enzyme may not be the most active one which also finds support from in vivo activity of functional proteins which always functions upon structural transformation to oligomer form rather than the native conformation. The higher activity of laccase in the micellar solution of both the ILs can be accounted to the availability of micellar interfaces for better interactions between substrate and enzyme in its altered form. In a different work, a similar behavior 
1 was observed for the peroxidase activity of Cytochrome c, which enhanced in the

2 vesicular solution of surfactant IL; cholinium dioctylsulfosuccinate (a surface active ionic

3 liquid) induced a conformational transition in the secondary structure of cytochrome c

4 with an enhanced peroxidase activity $(59,60)$.

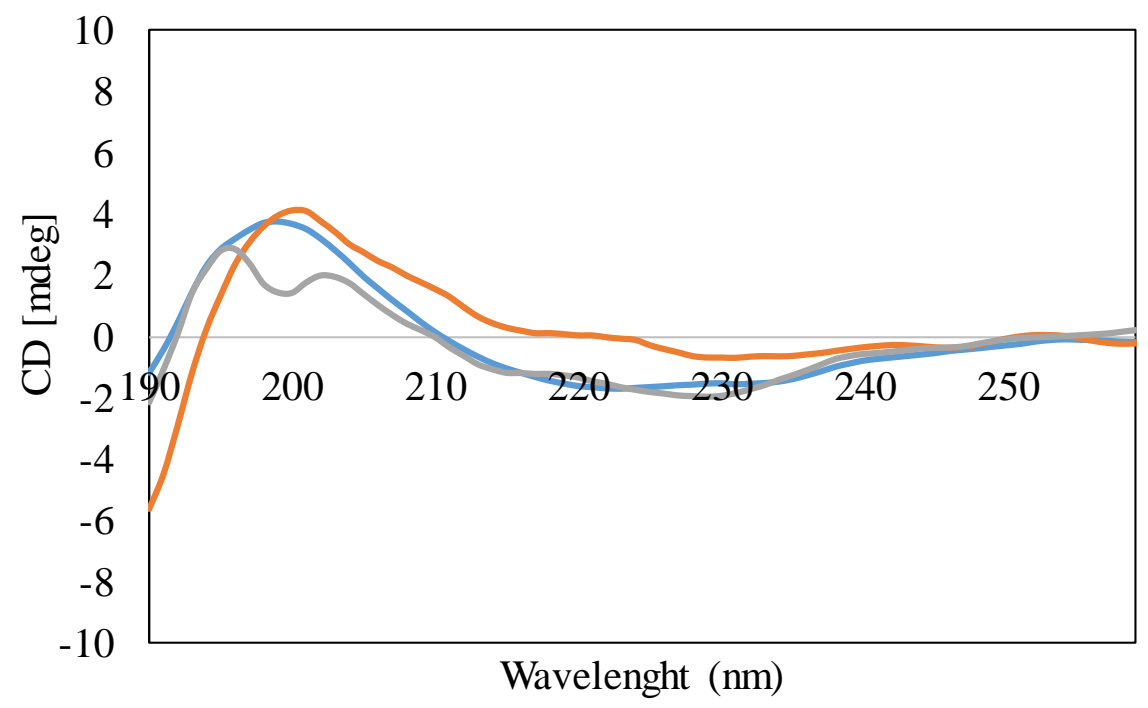

6

7 Fig. 4. CD spectra of aqueous solution of laccase (control), blue line; aqueous solution of laccase 8 and $\left[\mathrm{C}_{10} \mathrm{mim}\right] \mathrm{Cl}(1 \mathrm{mM})$, orange line; and aqueous solution of laccase and $\left[\mathrm{N}_{10111}\right] \mathrm{Br}(1 \mathrm{mM})$, 9 grey line.

10

11 To evaluate if the current laccase reaction occurs inside or outside the ILs micelles, 12 different mixtures containing $\left[\mathrm{N}_{10111}\right] \mathrm{Br}$, substrate (IC) and laccase were prepared: i) 13 [ $\left.\mathrm{N}_{10111}\right] \mathrm{Br}$ and laccase; ii) $\left[\mathrm{N}_{10111}\right] \mathrm{Br}$ and IC; and iii) $\left[\mathrm{N}_{10111}\right] \mathrm{Br}$, laccase and IC. After 2.5 $14 \mathrm{~h}$, all solutions were centrifuged in a progressive rotational speed aiming at precipitating 15 the ILs aggregates containing laccase and the substrate. The obtained precipitates were analyzed by optical microscopy. Figure 5 shows the macroscopic and microscopic

17 appearance of the different $\left[\mathrm{N}_{10111}\right] \mathrm{Br}$ aqueous solutions and respective precipitates. $\mathrm{A}$

18 blue precipitate with the mixture composed of [ $\left.\mathrm{N}_{10111}\right] \mathrm{Br}+\mathrm{IC}$ and a colorless precipitate 19 with the $\left[\mathrm{N}_{10111}\right] \mathrm{Br}+\mathrm{IC}+$ enzyme were obtained. From the analysis of the microscopic 
1 images shown in (Figure 5) it seems that IC is mostly confined inside the aggregates

2 formed by the $\left[\mathrm{N}_{10111}\right] \mathrm{Br}$ IL. These macroscopic results suggest that the oxidation of IC

3 takes place inside the micelles, where both the enzyme and the dye are incorporated thus

4 promoting an efficient and improved IC decolorization. Moreover, for this IL, the enzyme

5 activity was measured in the supernatant after a centrifugation step. No enzymatic activity

6 was detected, being one additional indication that the enzyme is inside the aggregates

7 formed by the $\left[\mathrm{N}_{10111}\right] \mathrm{Br}$ IL. These findings are in accordance with Liang et al. (61), who

8 suggested that the inner of micelles is a suitable mimetic environment of living cells,

9 supporting the enzymes "superactivity" in micelles cores.

10 The overall gathered results show that it is possible to improve the degradation of 11 hydrophobic dyes by enzymes using appropriate surfactant-based ILs. Furthermore, large aggregates are formed, which can be removed by precipitation or filtration, allowing the dyes removal and water treatment. Even if some IL is still present in the treated water, these have shown to be advantageous in the dyeing of wool, polyester, and cotton with the Disperse Red 13 dye in the absence of auxiliary agents (62). Accordingly, in the current work, we foresee the use of the treated water by the same textile industries in new dyeing steps, contributing to a significant decrease of the economic input and environmental footprint of these industries. 

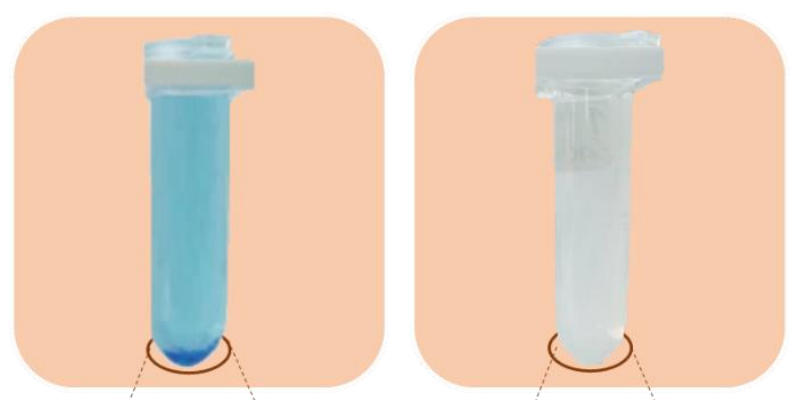

$\left[\mathrm{N}_{10333}\right] \mathrm{Br}$

Indigo carmine
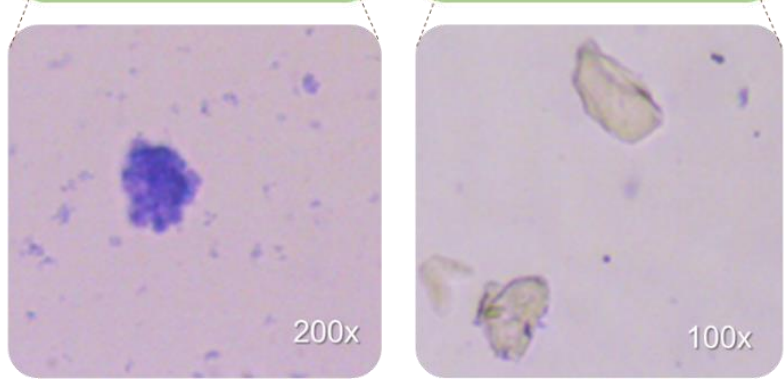

Fig. 5. Indigo carmine and $\left[\mathrm{N}_{10111}\right] \mathrm{Br}$ aqueous solutions and optical microscope images of the precipitate obtained after centrifugation.

\section{Conclusions}

In this work, we investigated and proposed the use of ILs with surfactant behavior to improve the degradation of the IC dye by laccase, which may allow the reuse of the discharged water by the textile industry. The activity of laccase in aqueous solutions of three families of ILs, namely 1-alkyl-3-methylimidazolium chloride $\left.\left(\left[\mathrm{C}_{n} \mathrm{mim}\right] \mathrm{Cl}\right]\right)$ and 1alkyltrimethylammonium bromide $\left(\left(\left[\mathrm{N}_{n 111}\right] \mathrm{Br}\right]\right)$ as cationic surfactants and cholinium carboxylate $\left([\mathrm{Ch}]\left[\mathrm{C}_{n} \mathrm{O}_{2}\right]\right)$ as anionic surfactants, was evaluated. A high activity of laccase was obtained with $\left[\mathrm{N}_{10111}\right] \mathrm{Br}$ and $\left[\mathrm{C}_{10} \mathrm{mim}\right] \mathrm{Cl}$ at $75 \mathrm{mM}$, above their $\mathrm{CMC}$, and where ca. $90 \%$ of the enzyme residual activity is maintained. These ILs were then investigated to improve the color removal of IC by laccase. It was demonstrated that the use of the $\left[\mathrm{N}_{10111}\right] \mathrm{Br}$ IL is favorable for the enzymatic degradation of the dye. Remarkably, a significantly higher and fast decolorization of the IC dye was obtained, and within $0.5 \mathrm{~h}$ 
1 it was possible to achieve a color removal percentage of $82 \%$ (against $6 \%$ achieved

2 without IL). After $24 \mathrm{~h}, 93 \%$ of the dye decolorization was accomplished in the presence

3 of the same IL at the same concentration. Overall, this works shows the possibility of

using surfactant-based ILs instead of the commonly used mediators or enzymes mutation approaches to significantly improve the enzymatic degradation of textile dyes.

\section{Acknowledgments}

This work was developed within the scope of the project CICECO-Aveiro Institute of Materials, FCT Ref. UID/CTM/50011/2019, financed by national funds through the FCT/MCTES. This work was also financially supported by the project POCI-01-0145FEER-031106 (IonCytDevice) and POCI-01-0145-FEDER-031268 funded by FEDER, through COMPETE2020 - Programa Operacional Competitividade e Internacionalização (POCI), and by national funds (OE), through FCT/MCTES. Ana P.M. Tavares acknowledges FCT for the Investigator Programme (IF/01634/2015).

\section{References}

1. Shah A, Shahzad S, Munir A, Nadagouda MN, Khan GS, Shams DF, et al. Micelles as Soil and Water Decontamination Agents. Chem Rev. 2016 May;116(10):6042-74.

2. Hayat H, Mahmood Q, Pervez A, Bhatti ZA, Baig SA. Comparative decolorization of dyes in textile wastewater using biological and chemical treatment. Sep Purif Technol. 2015; 154:149-53.

3. Vineta S, Silvana Z, Sanja R, Golomeova S. Methods for waste waters treatment in textile industry. In: International Scientific Conference - "UNITECH 2014" - Gabrovo. 2014.

4. De Jager D, Sheldon MS, Edwards W. Colour removal from textile wastewater using a pilot-scale dual-stage MBR and subsequent RO system. Sep Purif Technol. 2014;135:135-44.

5. F. Orts, A.I. del Río, J. Molina, J. Bonastre FC. Study of the Reuse of Industrial Wastewater After Electrochemical Treatment of Textile Effluents without External Addition of Chloride. Int J Electrochem Sci. 2019;14:1733 - 1750.

6. Jiayi Wang LL and FF. Improving the Indigo Carmine Decolorization Ability of a Bacillus amyloliquefaciens Laccase by Site-Directed Mutagenesis. Catalysts. 2017;7(9):275.

7. Sharma B, Dangi AK, Shukla P. Contemporary enzyme based technologies for 
bioremediation: A review. J Environ Manage. 2018 Mar;210:10-22.

8. Riera-Torres M, Gutiérrez-Bouzán C. Optimisation of the electrochemical and UV combined treatment to remove colour and organic halogenated compounds of textile effluents. Sep Purif Technol. 2012;98:375-82.

9. Mojsov KD. Biotechnological applications of laccases in the textile industry. Adv Technol. 2014;3(1):76-9.

10. Durán N, Esposito E. Potential applications of oxidative enzymes and phenoloxidase-like compounds in wastewater and soil treatment: a review. Appl Catal B Environ. 2000;28(2):83-99.

11. Rao CSK and SS. Role of Microbial Enzymes in the Bioremediation of Pollutants: A Review. Enzyme Res. 2011;

12. Ana P. M.Tavares AX. Application of Oxidative Enzymes in the Treatment of Industrial Effluents. 2014. 193-214 p.

13. Husain M, Husain Q. Applications of Redox Mediators in the Treatment of Organic Pollutants by Using Oxidoreductive Enzymes: A Review. Crit Rev Environ Sci Technol. 2007 Dec;38(1):1-42.

14. Tisma M, Znidarsic-Plazl P, Vasic-Racki D, Zelic B. Optimization of laccase production by Trametes versicolor cultivated on industrial waste. Appl Biochem Biotechnol. 2012 Jan;166(1):36-46.

15. Adinarayana Kunamneni, Antonio Ballesteros FJP and MA. Fungal laccase - a versatile enzyme for biotechnological applications. Commun Curr Res Educ Top Trends Appl Microbiol. 2007;1:233-45.

16. Xu H-M, Sun X-F, Wang S-Y, Song C, Wang S-G. Development of laccase/graphene oxide membrane for enhanced synthetic dyes separation and degradation. Sep Purif Technol. 2018;204:255-60.

17. Moreira S, Milagres AMF, Mussatto SI. Reactive dyes and textile effluent decolorization by a mediator system of salt-tolerant laccase from Peniophora cinerea. Sep Purif Technol. 2014;135:183-9.

18. Pezzella C, Guarino L, Piscitelli A. How to enjoy laccases. Cell Mol Life Sci. 2015 Mar;72(5):923-40.

19. J. Chapman, A. Ismail CD. Industrial applications of enzymes: Recent advances, techniques, and outlooks. Catalysts. 2018;8:238.

20. Sintra TE, Ventura SPM, Coutinho JAP. Superactivity induced by micellar systems as the key for boosting the yield of enzymatic reactions. J Mol Catal B Enzym. 2014;107:14051 .

21. Pinto PCAG, Saraiva MLMFS, Lima JLFC. Oxidoreductase behavior in ionic liquids: a review. Anal Sci. 2008 Oct;24(10):1231-8.

22. Cunha E, Passos MLC, Pinto PCAG, Saraiva MLMFS. Improved activity of $\alpha$ chymotrypsin in mixed micelles of cetyltrimethylammonium bromide (CTAB) and ionic liquids: A kinetic study resorting to sequential injection analysis. Colloids Surfaces B Biointerfaces. 2014;118:172-8.

23. Scovazzo P, Visser AE, Davis JH, Rogers RD, Koval CA, DuBois DL, et al. Supported Ionic Liquid Membranes and Facilitated Ionic Liquid Membranes. In: Ionic Liquids. American Chemical Society; 2002. p. 6-69. (ACS Symposium Series; vol. 818). 
24. Welton T. Ionic liquids in catalysis. Coord Chem Rev. 2004;248(21):2459-77.

25. Zhao $\mathrm{H}$. Methods for stabilizing and activating enzymes in ionic liquids - a review. $\mathbf{J}$ Chem Technol Biot. 2010;85:891-907.

26. U. Preiss, C. Jungnickel, J. Thöming, I. Krossing, J. Łuczak, M. Diedenhofen, A. Klamt. Predicting the Critical Micelle Concentrations of Aqueous Solutions of Ionic Liquids and Other Ionic Surfactants. Chem - A Eur J. 2009 Sep;15(35):8880-5.

27. Goldfeder M, Fishman A. Modulating enzyme activity using ionic liquids or surfactants. Appl Microbiol Biotechnol. 2014 Jan;98(2):545-54.

28. Greaves TL, Drummond CJ. Ionic liquids as amphiphile self-assembly media. Chem Soc Rev. 2008;37(8):1709-26.

29. Łuczak J, Hupka J, Thöming J, Jungnickel C. Self-organization of imidazolium ionic liquids in aqueous solution. Colloids Surfaces A Physicochem Eng Asp. 2008;329(3):12533.

30. Quental M V., Caban M, Pereira MM, Stepnowski P, Coutinho JAP, Freire MG. Enhanced extraction of proteins using cholinium-based ionic liquids as phase-forming components of aqueous biphasic systems. Biotechnol J. 2015;10(9).

31. U. More, Z. Vaid, P. Bhamoria, A. Kumar NIM. Effect of [Cnmim][Br] Based Ionic Liquids on the Aggregation Behavior of Tetradecyltrimethylammonium Bromide in Aqueous Medium. J Solut Chem. 2015;44:850-74.

32. de Faria ELP, Gomes M V, Claudio AFM, Freire CSR, Silvestre AJD, Freire MG. Extraction and recovery processes for cynaropicrin from Cynara cardunculus L. using aqueous solutions of surface-active ionic liquids. Biophys Rev. 2018 Jun;10(3):915-25.

33. Vicente FA, Cardoso IS, Sintra TE, Lemus J, Marques EF, Ventura SPM, et al. Impact of Surface Active Ionic Liquids on the Cloud Points of Nonionic Surfactants and the Formation of Aqueous Micellar Two-Phase Systems. J Phys Chem B. 2017;121(37):8742-55.

34. S. Kim, P.A. Thiessen, E.E. Bolton, J. Chen, G. Fu, A. Gindulyte, L. Han, J. He, S. He, B.A. Shoemaker, J. Wang, B. Yu, J. Zhang SHB. PubChem Substance and Compound databases.

35. Rodriguez O, Cristovao RO, Tavares APM, Macedo EA. Study of the alkyl chain length on laccase stability and enzymatic kinetic with imidazolium ionic liquids. Appl Biochem Biotechnol. 2011 Jun;164(4):524-33.

36. van Rantwijk F, Sheldon RA. Biocatalysis in Ionic Liquids. 2007 [cited 2018 Sep 25];

37. Savelli G, Spreti N, Di Profio P. Enzyme activity and stability control by amphiphilic selforganizing systems in aqueous solutions. Curr Opin Colloid Interface Sci. 2000;5(1):1117.

38. Zhao H. Protein stabilization and enzyme activation in ionic liquids: specific ion effects. J Chem Technol Biotechnol [Internet]. 2016 Jan [cited 2019 Apr 14];91(1):25-50. Available from: http://www.ncbi.nlm.nih.gov/pubmed/26949281

39. Liu H, Wu X, Sun J, Chen S. Stimulation of Laccase Biocatalysis in Ionic Liquids: A Review on Recent Progress. Curr Protein Pept Sci [Internet]. 2017 Nov 21 [cited 2018 Aug 21];19(1):100-11.

40. Yang Z. Hofmeister effects: an explanation for the impact of ionic liquids on biocatalysis. J Biotechnol. 2009 Oct;144(1):12-22. 
41. Campos R, Kandelbauer A, Robra KH, Cavaco-Paulo A, Gübitz GM. Indigo degradation with purified laccases from Trametes hirsuta and Sclerotium rolfsii. J Biotechnol. 2001;89(2):131-9.

42. Thurston CF. The structure and function of fungal laccases. Microbiology. 1994;140:1926.

43. Elba Ortiz, Violeta Gómez-Chávez, Carlos M. Cortés-Romero, Hugo Solís, Rubén RuizRamos SL-S. Degradation of Indigo Carmine Using Advanced Oxidation Processes: Synergy Effects and Toxicological Study. J Environ Prot (Irvine, Calif). 2016;7:1693706.

44. Ho K-KM. Degradation of indigo and indigo carmine with an enzyme isolated from bacteria strain ATCC. p. US5457043A.

45. Ben Younes S, Sayadi S. Detoxification of Indigo carmine using a combined treatment via a novel trimeric thermostable laccase and microbial consortium. J Mol Catal B Enzym. 2013;87:62-8.

46. E. Abadulla, T. Tzanov, S. Costa, K.-H. Robra, A. Cavaco-Paulo GMG. Decolorization and Detoxification of Textile Dyes with a Laccase from Trametes hirsuta. Appl Environ Microbiol. 2000;66:3357.

47. Champagne P-P, Ramsay JA. Dye decolorization and detoxification by laccase immobilized on porous glass beads. Bioresour Technol. 2010;101(7):2230-5.

48. Kunamneni A, Ghazi I, Camarero S, Ballesteros A, Plou FJ, Alcalde M. Decolorization of synthetic dyes by laccase immobilized on epoxy-activated carriers. Process Biochem. 2008;43(2):169-78.

49. Wong Y, Yu J. Laccase-catalyzed decolorization of synthetic dyes. Water Res. 1999;33(16):3512-20.

50. Forootanfar H, Moezzi A, Aghaie-Khozani M, Mahmoudjanlou Y, Ameri A, Niknejad F, et al. Synthetic dye decolorization by three sources of fungal laccase. Iranian J Environ Health Sci Eng. 2012 Dec;9(1):27.

51. Shipovskov S, Gunaratne HQN, Seddon KR, Stephens G. Catalytic activity of laccases in aqueous solutions of ionic liquids. Green Chem. 2008;10(7):806-10.

52. Rehmann L, Ivanova E, Ferguson JL, Gunaratne HQN, Seddon KR, Stephens GM. Measuring the effect of ionic liquids on laccase activity using a simple, parallel method. Green Chem. 2012;14(3):725-33.

53. Kushch O V, O. I, Hordieieva, Zosenko OO, Shendrik AN. Comparison of N-Hydroxy Compounds as Mediators in Laccase-Catalysed Decolorization of Indigo Carmine. ChemistrySelect. 2019 Apr;4(13):3905-13.

54. Xu G, Wang J, Yin Q, Fang W, Xiao Y, Fang Z. Expression of a thermo- and alkali-philic fungal laccase in Pichia pastoris and its application. Protein Expr Purif. 2019;154:16-24.

55. Gupta V, Balda S, Gupta N, Capalash N, Sharma P. Functional substitution of domain 3 (T1 copper center) of a novel laccase with $\mathrm{Cu}$ ions. Int J Biol Macromol. 2019;123:105261.

56. Louis-Jeune C, Andrade-Navarro MA, Perez-Iratxeta C. Prediction of protein secondary structure from circular dichroism using theoretically derived spectra. Proteins Struct Funct Bioinforma [Internet]. 2012 Feb [cited 2019 Sep 29];80(2):374-81.

57. Bharmoria P, Rao KS, Trivedi TJ, Kumar A. Biamphiphilic Ionic Liquid Induced Folding Alterations in the Structure of Bovine Serum Albumin in Aqueous Medium. J Phys Chem 
B [Internet]. 2014 Jan 9 [cited 2019 Sep 29];118(1):115-24.

58. Bharmoria P, Mehta MJ, Pancha I, Kumar A. Structural and functional stability of cellulase in aqueous-biamphiphilic ionic liquid surfactant solution. J Phys Chem B. 2014 Aug;118(33):9890-9.

59. Bharmoria P, Trivedi TJ, Pabbathi A, Samanta A, Kumar A. Ionic liquid-induced all- $\alpha$ to $\alpha+\beta$ conformational transition in cytochrome $\mathrm{c}$ with improved peroxidase activity in aqueous medium. Phys Chem Chem Phys. 2015;17(15):10189-99.

60. Bharmoria P, Kumar A. Unusually high thermal stability and peroxidase activity of cytochrome $\mathrm{c}$ in ionic liquid colloidal formulation. Chem Commun [Internet]. 2016 Dec 23 [cited 2019 Sep 29];52(3):497-500.

61. Y. Liang, X. Yuan, G. Zeng, H. Zhong, H. Li WW. Effects of surfactants on enzymecontaining reversed micellar system. Sci China Chem. 2011;54:715.

62. Bianchini R, Cevasco G, Chiappe C, Pomelli CS, Rodríguez Douton MJ. Ionic Liquids Can Significantly Improve Textile Dyeing: An Innovative Application Assuring Economic and Environmental Benefits. ACS Sustain Chem Eng. 2015 Sep;3(9):2303-8. 
3 Improvements in the enzymatic degradation of textile dyes

*Corresponding author 
Table S1. Relative laccase activity (\%) in aqueous solutions of ILs.

2

\begin{tabular}{cccccc}
\hline & \multicolumn{5}{c}{ Relative laccase activity (\%) } \\
\cline { 2 - 6 } IL & $\mathbf{5}$ & \multicolumn{5}{c}{ IL concentration (mM) } \\
\cline { 2 - 6 } & $100.0 \pm 3.0$ & $95.2 \pm 2.9$ & $83.2 \pm 2.5$ & $71.7 \pm 2.2$ & $42.7 \pm 1.3$ \\
\hline$\left[\mathrm{N}_{8111}\right] \mathrm{Br}$ & $92.4 \pm 2.8$ & $88.6 \pm 2.7$ & $86.4 \pm 2.6$ & $43.3 \pm 1.3$ & $7.1 \pm 0.2$ \\
{$\left[\mathrm{~N}_{10111}\right] \mathrm{Br}$} & $34.8 \pm 1.0$ & $27.6 \pm 0.8$ & $9.5 \pm 0.3$ & $10.8 \pm 0.3$ \\
{$\left[\mathrm{~N}_{12111}\right] \mathrm{Br}$} & $80.4 \pm 2.4$ & $17.5 \pm 0.5$ & $10.2 \pm 0.3$ & $7.3 \pm 0.2$ & $8.9 \pm 0.3$ \\
{$\left[\mathrm{~N}_{14111}\right] \mathrm{Br}$} & $60.2 \pm 1.8$ & $95.2 \pm 2.9$ & $85.4 \pm 2.6$ & $45.2 \pm 1.7$ & $27.3 \pm 0.8$ \\
\hline$\left[\mathrm{C}_{8} \mathrm{mim}\right] \mathrm{Cl}$ & $100.0 \pm 3.0$ & $95.2 \pm 2.9$ & $90.4 \pm 2.7$ & $18.5 \pm 0.6$ & $12.4 \pm 0.4$ \\
{$\left[\mathrm{C}_{10} \mathrm{mim}\right] \mathrm{Cl}$} & $100.0 \pm 3.0$ & $13.8 \pm 0.4$ & $2.8 \pm 0.1$ & $1.6 \pm 0.1$ & $0.8 \pm 0.1$ \\
{$\left[\mathrm{C}_{12} \mathrm{mim}\right] \mathrm{Cl}$} & $92.8 \pm 2.8$ & $7.56 \pm 0.2$ & $0.7 \pm 0.1$ & $0.1 \pm 0.1$ & $1.6 \pm 0.1$ \\
{$\left[\mathrm{C}_{14} \mathrm{mim}\right] \mathrm{Cl}$} & $103.0 \pm 3.1$ & $29.8 \pm 1.8$ & $21.7 \pm 0.6$ & $14.0 \pm 0.4$ & $12.5 \pm 2.3$ \\
\hline$[\mathrm{Ch}]\left[\mathrm{C}_{8} \mathrm{O}_{2}\right]$ & $49.1 \pm 1.5$ & $49.9 \pm 1.5$ & $48.4 \pm 1.5$ & $28.8 \pm 0.9$ & $17.6 \pm 1.5$ \\
{$[\mathrm{Ch}]\left[\mathrm{C}_{10} \mathrm{O}_{2}\right]$} & $49.7 \pm 1.5$ & 49.9 & $0.5 \pm 0.1$ & $0.5 \pm 0.1$ \\
{$[\mathrm{Ch}]\left[\mathrm{C}_{12} \mathrm{O}_{2}\right]$} & $32.2 \pm 2.0$ & $20.8 \pm 0.6$ & $13.6 \pm 0.4$ & 0.5 & $2.7 \pm 0.1$ \\
{$[\mathrm{Ch}]\left[\mathrm{C}_{14} \mathrm{O}_{2}\right]$} & $24.6 \pm 1.7$ & $0.6 \pm 0.1$ & $0.2 \pm 0.1$ & $1.1 \pm 0.1$ & \\
\hline
\end{tabular}

3

4 


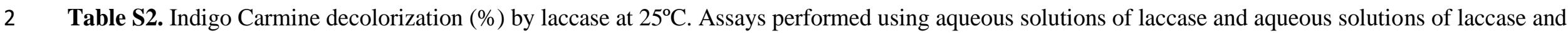
IL (75 and $20 \mathrm{mM}$ ).

\begin{tabular}{|c|c|c|c|c|c|}
\hline \multirow[b]{2}{*}{ Time (h) } & \multicolumn{5}{|c|}{ Indigo carmine decolorization (\%) } \\
\hline & Laccase & $\begin{array}{c}\text { Laccase }+\left[\mathrm{N}_{10111}\right] \mathrm{Br} \\
75 \mathrm{mM}\end{array}$ & $\begin{array}{c}\text { Laccase }+\left[\mathrm{C}_{10} \mathrm{mim}\right] \mathrm{Cl} \\
75 \mathrm{mM}\end{array}$ & $\begin{array}{c}\text { Laccase }+\left[\mathrm{N}_{10111}\right] \mathrm{Br} \\
20 \mathrm{mM}\end{array}$ & $\begin{array}{c}\text { Laccase }+\left[\mathrm{C}_{10} \mathrm{mim}\right] \mathrm{Cl} \\
20 \mathrm{mM}\end{array}$ \\
\hline 0.5 & $6.3 \pm 3.8$ & $82.4 \pm 2.1$ & $30.3 \pm 1.7$ & $15.1 \pm 1.8$ & $10.9 \pm 1.5$ \\
\hline 1.0 & $10.6 \pm 1.2$ & $80.5 \pm 4.4$ & $43.3 \pm 1.5$ & $18.8 \pm 1.2$ & $14.4 \pm 2.3$ \\
\hline 1.5 & $16.6 \pm 2.0$ & $81.3 \pm 3.4$ & $51.0 \pm 2.6$ & $22.1 \pm 2.4$ & $17.2 \pm 1.7$ \\
\hline 2.0 & $20.5 \pm 1.9$ & $82.0 \pm 3.2$ & $57.0 \pm 1.0$ & $25.4 \pm 1.1$ & $20.1 \pm 0.8$ \\
\hline 2.5 & $24.5 \pm 2.8$ & $83.5 \pm 2.3$ & $61.7 \pm 3.1$ & $28.1 \pm 1.7$ & $23.9 \pm 1.9$ \\
\hline 24 & $29.0 \pm 1.5$ & $92.5 \pm 3.1$ & $70.1 \pm 3.5$ & $36.3 \pm 1.6$ & $29.9 \pm 1.0$ \\
\hline
\end{tabular}



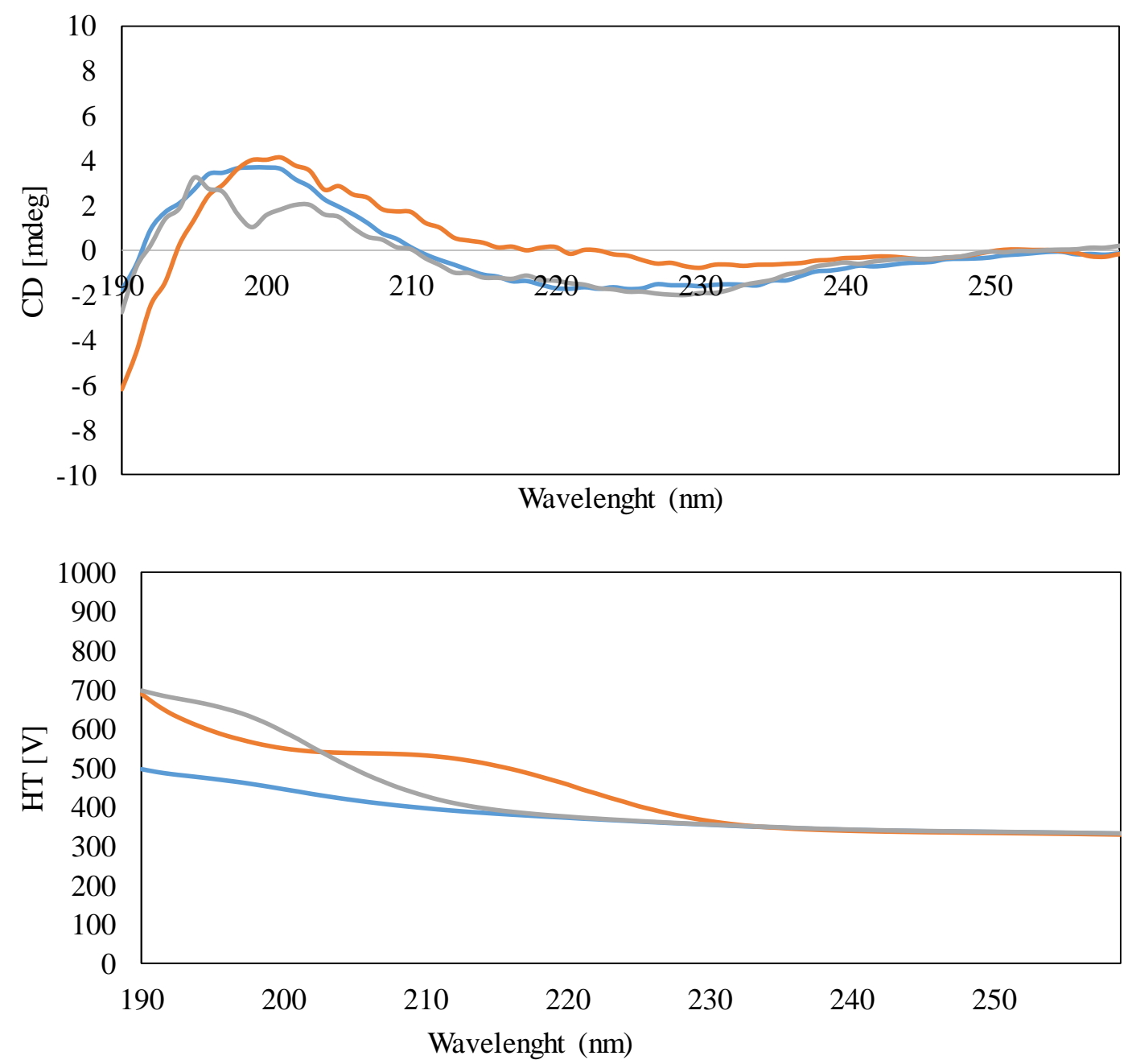

1

2 Figure S1. CD spectra of aqueous solution of laccase (Control), blue line; aqueous solution of 3 laccase and $\left[\mathrm{C}_{10} \mathrm{mim}\right] \mathrm{Cl}(1 \mathrm{mM})$, orange line; and aqueous solution of laccase and $\left[\mathrm{N}_{10111}\right] \mathrm{Br}(1$ 4 $\mathrm{mM}$ ), grey line. 